\title{
The Efectiveness of Jamblang (Syzygium cumini) Leaves Extract Inclusion Skim Milk-Egg Yolk Extender on Motility and Viability of Aceh Cattle Spermatozoa during Pre-Freezing and Post-Thawing
}

\author{
Cut Intan Novita ${ }^{1}$, Faqihuddin Nasution ${ }^{1} \&$ Eka Meutia Sari ${ }^{1}$ \\ ${ }^{1}$ Department of Animal Science, Faculty of Agriculture, Universitas Syiah Kuala, Darussalam, Banda Aceh 23111, \\ Indonesia, and Research Centre of Aceh Cattle and Local Animal, USK, Indonesia \\ Correspondence: Cut Intan Novita, Department of Animal Science, Faculty of Agriculture, Universitas Syiah \\ Kuala, and Research Centre of Aceh Cattle and Local Animal, Indonesia. E-mail: cutintan@unsyiah.ac.id
}

Received: August 24, 2021 Accepted: September 22, 2021 Online Published: September 24, 2021

\begin{abstract}
The process of semen freezing causes an increase in free radicals concentration which can damage spermatozoa. The addition of natural ingredients in semen diluent is expected to solve this challenges. One of the natural ingredients that can be used is jamblang (Syzygium cumini) leaves. The objective of the current study was to investigate the quality of spermatozoa in Aceh cattle which was added with jamblang leaves extract in skim milkegg yolk extender during pre-freezing and post-thawing. This study applied Completely Randomized Design (CRD) with 5 treatments and 5 replications. The treatments consisted of J0 = skim milk-egg yolk; J1 = skim milk-egg yolk + jamblang leaves extract $0.2 \%$; $\mathrm{J} 2=$ skim milk-egg yolk + jamblang leaves extract $0.4 \%$; J3 = skim milkegg yolk + jamblang leaves extract $0.6 \%$; and $\mathrm{J} 4=$ skim milk-egg yolk + jamblang leaves extract $0.8 \%$. The parameters observed in this study were the percentage of motility and viability of frozen semen of Aceh cattle. The data obtained were analyzed using Analysis of Variance (ANOVA) and if differences were found, then it would be continued with Duncan's Multiple Distance test. The results showed that the addition of jamblang leaves extract in egg yolk skim milk significantly affected the percentage of motility during pre-freezing and post-thawing, significantly affected spermatozoa viability during pre-freezing and significantly affected the spermatozoa viability during post-thawing. $\mathrm{J} 3$ treatment (jamblang leaves extract $0.6 \mathrm{gram} / 100 \mathrm{ml}$ ) it should be higher than the other treatment, where the percentage of motility at pre-freezing and post-thawing were $55.48 \%$ and $52.71 \%$, respectively, and the percentage of viability during pre-freezing and post-thawing were $56.59 \%$ and $53.94 \%$, respectively. It was concluded that the addition of jamblang leaves extract in the skim milk-egg yolk extender affected the percentage of spermatozoa motility and viability of Aceh cattle during pre-freezing and post-thawing.
\end{abstract}

Keywords: Spermatozoa of Aceh Cattle, Jamblang (Syzygium cumini) leaves extract, motility, viability, prefreezing, post-thawing

\section{Introduction}

The population of Aceh cattle which have been determined as Indonesian germplasm has decreased in the last 4 (four) years. Its population was 86,618 cattle in 2017, but decreased to 76,811 cattle in 2020 (iSIKHNAS, 2020). Therefore, this fact urges the efforts to increase the population of Aceh cattle sustainably.

One of the methods to increase the population of Aceh cattle is the application of Artificial Insemination (AI). The quality of semen used in the artificial insemination program is affected by the semen processing process starting from the storage, dilution, equilibration, and freezing (Fraser and Strzezek, 2005; Baumber et al., 2005). Furthermore, thawing method employed also has a significant role in determining the semen quality. The most critical part of the freezing process is the freezing process itself (Ozkavukcu et al., 2008; Ezzati et al., 2020;) and the thawing period (Garcia et al., 2010). During the freezing, water molecules were released massively from the cell, causing an increase in the concentration of intracellular electrolytes and the formation of ice crystals (Rasul et al., 2001; Rodriguez-Martinez et al., 2008; Baust et al., 2009). Meanwhile, during the thawing process, semen experiences heavy pressure due to a drastic increase in temperature. Such conditions increased the metabolic activities which further lead to the increase of metabolic products, which is the concentration of free radical (Chatterjee and Gagnon, 2001; Kumar et al., 2011). All of these negative effects will decrease the motility and viability of spermatozoa (Mansour et al., 2010). 
The quality of semen can be maintained through the dilution process. This process needs a good extender that does contain nutrients, anti-cold shock, cryoprotectants, and antioxidants that can maintain the quality of semen during the equilibration to freezing process (Schafer-Somi et al., 2006). Skim milk-egg yolk can be utilized as extender because skim milk contains protein, lactose, water, and little fat (Pagl et al., 2006). In addition, egg yolks and milk contain phospholipids and lecithin which can protect spermatozoa from cold shock during the freezing process (Amirat et al., 2004). The main content of milk is lecithin which can protect spermatozoa from cold stress during the freezing process (Feradis, 2009). Egg yolk is a food provider, energy source, and intracellular protector of spermatozoa from cold shock conditions during freezing, and provides a buffer effect against spermatozoa (Aboagla and Terada, 2004; Alcay et al., 2016). In order to overcome plasma membrane damage caused by free radicals, it needs additional antioxidants in the diluent. According to Leao et al. (2021), the addition of antioxidants in semen diluents can reduce oxidative stress and can increase fertilization power. One of the natural ingredients that can be used is jamblang (Syzygium cumini) leaves. Jamblang leaves contain antioxidant substances including flavonoids, phenolics (Ruan et al., 2008; Mohamed et al., 2013), alkaloids, glycosides, saponins, tannins (Gowri and Vasantha, 2010), $\beta$-sitosterol, quercetin, and terpenoid (Sarma et al., 2020). In addition to being a natural antioxidant, as a diluent, jamblang leaves is also expected to save the cost of frozen semen production, because jamblang leaves are easy to obtain. Based on this background, it is necessary to further study the effect of the addition of jamblang (Syzygium cumini) leaves extract in skim milk-egg yolks extender on the motility and viability of Aceh cattle spermatozoa during pre-freezing and post-thawing.

\section{Material and Method}

The materials used in this research were $4 \mathrm{~kg}$ of jamblang leaves that were extract and fresh semen from a 10year-old Aceh cattle at Artificial Insemination Center of Saree Region, Aceh Besar. Completely Randomized Design (CRD) was applied in this research consisting of 5 treatments and 5 replications. These five treatments were included $\mathrm{J} 0$ = skim milk-egg yolk; $\mathrm{J} 1$ = skim milk-egg yolk + jamblang leaves extract of $0.2 \mathrm{gram} / 100 \mathrm{ml}$; $\mathrm{J} 2=$ skim milk-egg yolk + jamblang leaves extract of $0.4 \mathrm{gram} / 100 \mathrm{ml} ; \mathrm{J} 3=$ skim milk-egg yolk + jamblang leaves extract of $0.6 \mathrm{gram} / 100 \mathrm{ml}$; and J4 = skim milk-egg yolk + jamblang leaves extract of $0.8 \mathrm{gram} / 100 \mathrm{ml}$. Meanwhile, the parameters observed were the percentage of motility and viability of frozen semen of Aceh cattle.

The extraction process of jamblang (Syzygium cumini) leaves began with 1day air-drying and pulverizing the leaves until they formed simplicia powder. Simplicia powder was then macerated using 4 litters of $96 \%$ ethanol for 1000 grams of jamblang leaves. After 4 days of maceration process, the results were filtered, and then concentrated using a vacuum rotary evaporator at $40^{\circ} \mathrm{C}$ and a speed of $60 \mathrm{rpm}$ to obtain a paste-shaped extract.

Skim milk-egg yolk extender contained skim milk, egg yolk, fructose, distilled water, penicillin, and streptomycin. As much as $95 \mathrm{ml}$ of distilled water was heated at $37^{\circ} \mathrm{C}$, added with skim milk by 10 grams, and then homogenized. Furthermore, 1 gram of fructose was added into the erlenmeyer and homogenized, added by $5 \mathrm{ml}$ of egg yolk and then homogenized again. The solution was then steamed for 15-20 minutes until it reached room temperature of $37^{\circ} \mathrm{C}$. After the solution cooled down, $1000 \mathrm{IU} / \mathrm{ml}$ penicillin by 0.34 grams and $1000 \mathrm{IU} / \mathrm{ml}$ streptomycin by 0.16 grams were added. The solution was then stored in the refrigerator and settled for 3 (three) days to form a supernatant. The resulting supernatant was further used as the diluent, while the sediment was removed.

Semen was collected at 8 a.m. using an artificial vagina. Furthermore, macroscopic evaluations (volume, color, consistency, $\mathrm{pH}$, and odor) and microscopic evaluations (mass movement, concentration, motility, viability, and abnormality) were carried out to determine the quality of the fresh semen. The semen that were used must have at least ++ mass movement, motility above $70 \%$, and abnormalities below $20 \%$. After evaluating the quality of the semen, the semen was divided into 5 parts and added with skim milk-egg yolk and jamblang leaves extract according to the treatment and then homogenized. The desired concentration was 100 million spermatozoa/ml of the diluent.

The semen freezing process consisted of glycerolization, equilibration, filling (inserting to straw), sealing (straw sealing), pre-freezing, freezing, and post-thawing. The semen that has been added by diluent of skim milk-egg yolk and jamblang leaves extract according to the treatment was cooled in the refrigerator until it reached a temperature of $4{ }^{\circ} \mathrm{C}$. After that, glycerolization was conducted in the form of adding glycerol to semen gradually and slowly at a temperature of $4{ }^{\circ} \mathrm{C}$ for 1 hour aiming to prevent the occurrence of ice crystals and avoid the accumulation of intracellular electrolytes in spermatozoa. Then, equilibration was conducted at $4{ }^{\circ} \mathrm{C}$ for $3-4$ hours. Equilibration is the adaptation process of the spermatozoa intracellular fluid to the new environment. Furthermore, semen that has been diluted was filled into the straw by $0.25 \mathrm{ml} / \mathrm{straw}$, then sealed. Straw sealing was done by placing it on a straw rack $2-3 \mathrm{~cm}$ above the surface of liquid nitrogen for 9 minutes $\left(-110^{\circ} \mathrm{C}\right.$ to $\left.-140{ }^{\circ} \mathrm{C}\right)$, then the motility and viability of spermatozoa were examined. The next step was the freezing process that was performed 
at $-196^{\circ} \mathrm{C}$, in which the mini straws were put into liquid nitrogen and stored in a container for 7 days. Each sample was then thawed again by inserting the straw into water at $37^{\circ} \mathrm{C}$ for 15 seconds. Furthermore, evaluation of the motility and viability of spermatozoa were examined.

Fresh semen quality data were analyzed descriptively, while semen quality data before freezing (pre-freezing) and after thawing (post-thawing) were analyzed using Analysis of variance (Anova). Duncan Multiple Range Test were conducted if difference was found.

\section{Results and Discussion}

Quality of Fresh Semen of Aceh Cattle

Before further processing into frozen semen, fresh semen was evaluated to know the semen feasibility. The evaluation results of the semen quality of Aceh cattle were shown in Table 1.

Table 1. Quality of Fresh Semen of Aceh Cattle

\begin{tabular}{ll}
\hline Parameter & Observation Results \\
\hline Macroscopic & \\
Volume (ml) & $3.75 \pm 0.35$ \\
Color & Milky white \\
Consistency & Medium \\
Odor & Fishy (typical) \\
Acidic Level & $7.00 \pm 0.00$ \\
& \\
Microscopic & \\
Mass Movement & ++ \\
Motility (\%) & $81.5 \pm 7.78$ \\
Concentration $\left(10^{6} / \mathrm{ml}\right)$ & $1.68 \pm 0.60$ \\
Viability of sperm $(\%)$ & $92.68 \pm 1.76$ \\
Abnormality $(\%)$ & $5.86 \pm 0.02$ \\
\hline
\end{tabular}

The average volume of Aceh cattle semen obtained was $3.75 \pm 0.35 \mathrm{ml} /$ ejaculation with a range between 3.50 $5.00 \mathrm{ml}$. The average volume of semen obtained from Aceh cattle in this study was lower than Bali cattle which was $4.5 \pm 2.3 \mathrm{ml}$ (Ratnawati et al., 2008), Brahman cattle which was $4.72 \pm 1.82 \mathrm{ml}$ (Kuswahyuni, 2009), and Fries Holstein (FH) cattle which was 8.8 (Komariah et al., 2013), and limousine cattle which was $6.75 \pm 0.68 \mathrm{ml}$. However, it was relatively higher than the average semen volume of Ongole Crossbreed cattle which was $2.6 \pm$ $1.5 \mathrm{ml}$ (Affandhy et al., 2013). Such differences were caused by various factors, including nation, age, food level, temperature, frequency of storage, testicular size, and body weight (Fuerst-Waltl et al., 2006). This is supported by the statement given by (Hafez, 2004) that the characteristics of semen is affected by the age of the male and the interaction between age and the storage interval. Significant relationship also occurs between age and season so that it can affect the concentration of ejaculation volume and the percentage of spermatozoa motility (Brito et al., 2002; Boujenane and Boussaq, 2013).

The color of semen reflects the viscosity of the semen. In general, the color of fresh semen of Aceh cattle obtained in this study was milky white, while the consistency was medium (slightly runny) with a concentration of $1.68 \pm$ $0.60 \times 10^{9}$. This was reinforced by the opinion stated by Nugraha et al. (2019) that semen with medium consistency had a spermatozoa cell concentration of 1000 million - 2000 million or more per ml. The average $\mathrm{pH}$ of Aceh cattle semen obtained in this study was $7.00 \pm 0.00$ ranging from 6.8 to 7.2. This result is relatively the same as FH cattle semen which was $6.9 \pm 0.1$ (Komariah et al., 2013) and PO cattle which was $7.00 \pm 0.00$ (Sholikah et al., 2016) obtained in the previous study. Spermatozoa which has good quality has characteristics of having mass movement and motility with progressive movement. The mass movement of fresh semen of Aceh cattle obtained in this study was $(++)$. This was indicated by black clouds that are not so dark but they move fast. This result is similar to the previous report (Santoso, 2021) that the mass movement of bovine spermatozoa that are suitable for processing ranges from $(++)$ to $(+++)$. The observation results of the average spermatozoa were $1.68 \pm 0.60 \mathrm{x}$ $106 / \mathrm{ml}$ with a range of $1000-1200 \times 10^{6} \mathrm{sperm} / \mathrm{ml}$. The average spermatozoa concentration in Aceh cattle obtained in this study was relatively the same as the spermatozoa concentration in Limousine cattle of $1153.64 \pm 127.50 \mathrm{x}$ $10^{6} / \mathrm{ml}$ and Simmental cattle of $1129.75 \pm 180.99 \times 10^{6}$ spermatozoa/ml obtained in the previous research (Sukmawati et al., 2014). Motility or progressive movement of spermatozoa after ejaculation is always used as the 
easiest guide in evaluating the semen quality for further processing. Spermatozoa motility of fresh semen of Aceh cattle obtained was $81.5 \pm 7.78 \%$ with a range between $70.00 \%-83.00 \%$. This result is higher than the percentage of PO cattle motility obtained in the previous study which was $70.00 \pm 0.00 \%$ (Sholikah et al., 2016). The average percentage of living spermatozoa in the fresh semen of Aceh cattle obtained this study was $92.68 \pm 1.76 \%$ with a range of $90.00 \%$ to $95.00 \%$. This result is higher than the average percentage of living spermatozoa in Bali cattle obtained in the previous research which was 75\% (Savitri et al., 2014), but lower than the percentage of living spermatozoa in Bali cattle which was $88.03 \pm 3.07 \%$ (Ratnawati et al., 2008) and limousine cattle which was $94.08 \%$ (Sukmawati, 2014). The percentage of abnormal spermatozoa from fresh semen of Aceh cattle obtained in this study was $5.86 \pm 0.02 \%$ ranging from $7.00 \%$ to $11.00 \%$. The percentage of abnormal spermatozoa obtained in this study is relatively the same as revealed in the previous report (Dewi et al., 2012) that the percentage of abnormal spermatozoa in Bali cattle bred in Indonesia was $6.56 \pm 3.05 \%$, but higher than the previous study (Zulyazaini et al. al., 2016) in Aceh cattle, which was $3.52 \pm 8.40 \%$ and limousine cattle which was $4.33 \pm 1.2 \%$ (Sunami et al. 2017).

\section{Percentage of Spermatozoa Motility of Aceh Cattle due to the Addition of Jamblang Leaves Extract in the Skim Milk and Egg Yolk Extender during Pre-freezing and Post-thawing}

Spermatozoa motility is an important indicator used to determine the quality of semen. The percentages of spermatozoa with progressive motility on pre-freezing and post-thawing examinations after being provided with the treatment of various concentrations of jamblang leaves extract in the skim milk-egg yolk extender are presented in Table 2 .

Table 2. Percentage of Spermatozoa Motility of Aceh Cattle due to the Addition of Jamblang Leaves Extract in the Skim Milk and Egg Yolk extender during Pre-freezing

\begin{tabular}{cll}
\hline Treatments & \multicolumn{1}{c}{ Pre-freezing } & \multicolumn{1}{c}{ Observation Period } \\
& \multicolumn{1}{c}{ Post-thawing } \\
\hline $\mathrm{J} 0(0 \%)$ & $40.05^{\mathrm{cd}} \pm 3.05$ & $33.61^{\mathrm{cd}} \pm 4.85$ \\
$\mathrm{~J} 1(0.2 \%)$ & $31.77^{\mathrm{bc}} \pm 9.80$ & $29.59^{\mathrm{bc}} \pm 6.72$ \\
$\mathrm{~J} 2(0.4 \%)$ & $23.85^{\mathrm{a}} \pm 3.89$ & $20.22^{\mathrm{d}} \pm 4.70$ \\
$\mathrm{~J} 3(0.6 \%)$ & $55.85^{\mathrm{d}} \pm 6.48$ & $52.71^{\mathrm{d}} \pm 5.92$ \\
$\mathrm{~J} 4(0.8 \%)$ & $26.16^{\mathrm{ab}} \pm 5.19$ & $23.53^{\mathrm{ab}} \pm 3.73$ \\
\hline
\end{tabular}

The results of variance revealed that the addition of jamblang leaves extract in the skim milk and egg yolk extender significantly affected $(\mathrm{P}<0.01)$ the progressive motility of spermatozoa on pre-freezing examination. Further tests showed that there was significant difference between $\mathrm{J} 0$ treatment (skim milk-egg yolk) $(\mathrm{P}<0.01)$ and $\mathrm{J} 2$ treatment (skim milk-egg yolk + jamblang leaves extract of $0.4 \%$ ) and $\mathrm{J} 4$ (skim milk-egg yolk + jamblang leaves extract of $0.8 \%$ ). However, no differences were found between $\mathrm{J} 0$ treatment and $\mathrm{J} 1$ treatment (skim milk- egg yolk + jamblang leaves extract $0.2 \%$ ) and $\mathrm{J} 3$ treatment (skim milk-egg yolk + jamblang leaves extract $0.6 \%$ ). Furthermore, significant differences were also found between $\mathrm{J} 1$ treatment (skim milk-egg yolk + jamblang leaves extract $0.2 \%$ ) $(\mathrm{P}<0.01)$ and $\mathrm{J} 2$ treatment (skim milk-egg yolk + jamblang leaves extract $0.4 \%$ ) and $\mathrm{J} 4$ (skim milk- egg yolk + jamblang leaves extract $0.8 \%$ ). In addition, differences were also found between $\mathrm{J} 3$ treatment (skim milk-egg yolk + jamblang leaves extract $0.6 \%$ ) and $\mathrm{J} 1, \mathrm{~J} 2$ and $\mathrm{J} 4$ treatments. The highest percentage of spermatozoa motility was obtained from $\mathrm{J} 3$ treatment with the addition of jamblang leaves extract by $0.6 \%$ of diluent, reaching $55.48 \%$. This result was higher compared to the previous study conducted by Samsudewa and Suryawijaya (2008), which obtained $45 \%$ on spermatozoa motility of Simmental cow. Similarly, report from the research conducted by Umar and Maharani (2005) revealed that 9 minutes pre-freezing on limousine cattle provides $47.25 \%$ percentage of spermatozoa motility as well as the research report of Madyawati et al. (2013) which obtained percentage rate of 47.5\% from Holstein Friesian cattle. The percentage obtained in this study is still below the percentage of sperm motility of wagyu cattle as reported by Hanifi et al. (2016) using Andromed ${ }^{\circledR}$ diluent which was $58.33 \%$. According to Pratiwi et al. (2006) the damage of cold shock and the formation of ice crystals was not too high during the pre-freezing process compared to the process.

According to Buffone et al. (2012), decreased motility can also be caused by the thawing process. During thawing process, spermatozoa are highly susceptible to cell damage due to sudden changes in osmotic pressure caused by rapid thawing. The constant changes of temperature causes damage to the spermatozoa. 
Furthermore, the results of variance showed that the addition of jamblang leaves extract in the skim milk-egg yolk extender significantly affected $(\mathrm{P}<0.01)$ the spermatozoa motility during post-thawing examination. Further tests showed that there were significant differences between J0 treatment (skim milk-egg yolk) $(\mathrm{P}<0.01)$ and J2 treatment (skim milk-egg yolk + jamblang leaves extract $0.4 \%$ ) and $\mathrm{J} 4$ treatment (skim milk-egg yolk + jamblang leaves extract $0.8 \%$ ). However, no difference found between J1 treatment (skim milk-egg yolk + jamblang leaves extract $0.2 \%$ ) and $\mathrm{J} 3$ treatment (skim milk-egg yolk + jamblang leaf extract $0.6 \%$ ). In addition, significant differences were found between J1 treatment (skim milk-egg yolk + jamblang leaves extract $0.20 \%)(\mathrm{P}<0.01)$ and $\mathrm{J} 2$ treatment (skim milk-egg yolk + jamblang leaves extract $0.4 \%$ ) and $\mathrm{J} 4$ treatment (skim milk- egg yolk + jamblang leaves extract $0.8 \%$ ). J3 treatment (skim milk-egg yolk + jamblang leaves extract $0.6 \%$ ) was also different from J1, J2 and J4. The highest percentage of spermatozoa motility during post-thawing process (52.71\%) was obtained from $\mathrm{J} 3$ treatment, while the lowest was found in $\mathrm{J} 2$ treatment $(20.22 \%)$.

Spermatozoa motility is one of the benchmarks in evaluating semen to be used in artificial insemination, but the microscopic evaluation on spermatozoa motility is subjective (Gillan et al., 2004). In addition, Petyim et al. (2014) also revealed that the minimum requirement for individual sperm motility in post-thawing process to be used in artificial insemination is $40 \%$. Based on this opinion, frozen semen of Aceh cattle in the skim milk-egg yolk extender added with jamblang leaves extract by $0.60 \%$ (J3) has met the requirements to be used in the artificial insemination, since its post-thawing motility percentage was $52.71 \%$. Such situation was assumed because the treatment has optimized the rate of fructolysis which causes the energy needs to live and move spermatozoa fulfilled. Jamblang leaves extract containing antioxidants with diluent of $0.6 \%$ (J3) can bind free radicals so as to prevent lipid peroxidation which can inhibit glycolysis and motility (Thuwanut et al., 2008). In J4 treatment (skim milk-egg yolk + addition of jamblang leaves extract of $0.8 \%$ ), post-thawing motility decreased. This indicates that the dose was not suitable to be used as a diluent. According to Basavaraja and Hegde (2004), the addition of inappropriate diluent as a medium for spermatozoa can be toxic to spermatozoa. Signs of cold shock or nonisotonic media with the semen will cause circular motions. When Spermatozoa stop moving, they are considered dead (Feradis, 2009).

Motility is the progressive forward movement of spermatozoa. This progressive movement has an important role in the success of fertilization (Kostaman and Sutama, 2006). The respiration process in spermatozoa metabolism produces lactic acid. The longer the respiration process, the more lactic acid produced. Lactic acid has an effect on reducing the life of spermatozoa motility (Ferramosca and Zara, 2014). Spermatozoa motility depends on mitochondrial function. Adenosine Triphosphate (ATP) is produced by oxidative phosphorylation in the mitochondrial membrane and transferred to microtubules as energy for motility, therefore the decrease in sperm motility due to clotting is believed to be related to mitochondrial damage. Sperm motility can occur if the sperm has a membrane that functions properly to produce energy for movement. During the freezing process, extreme changes in temperature and osmolality occur so that it will damage the lipid composition of the plasma membrane which has an effect on the decrease of sperm motility (Januskauskas et al., 2003).

Comparison of spermatozoa with progressive motility from pre-freezing process to post-thawing shows varied numbers. It can be seen in Figure 1.

\section{Percentage of Spermatozoa Motility at Pre-freezing and Post thawing Process}



Figure 1. Comparison of Percentage of Spermatozoa Motility at Pre-freezing and Post thawing Process 
Figure 1 shows the best percentage decrease in motility (4.99\%) was found in J3 treatment (addition of jamblang leaves extract of $0.6 \%$ ), while the highest decrease $(16.07 \%)$ was found in the treatment without the addition of jamblang leaves extract. Therefore, it can be summed up that the addition of jamblang leaves extract can reduce the percentage decrease in motility from the pre-freezing stage to the post-thawing stage. This condition proves that the antioxidants contained in jamblang leaves can suppress cell membrane damage due to cold shock. In accordance with the results of previous research performed by Bucak et al. (2008), it was discovered that antioxidant additives can be used to increase the efficiency of sperm cryopreservation, where the use of an antioxidant (cysteine) gave the best results for post-thawing spermatozoa motility $(61.0 \pm 1.9 \%)$. It was assumed that during the freezing and thawing process, the spermatozoa was damaged so that it affects the stability and living functions of the cell membrane, thus the percentage of spermatozoa motility after thawing decreased. This is supported by the statement made by Nagy et al. (2004) that $50 \%$ of spermatozoa will die after freezing and thawing process. Spermatozoa can be destroyed rapidly in the cooling and freezing process, in which during the thawing process, spermatozoa are highly susceptible to cell damage due to sudden changes in osmotic pressure caused by rapid thawing. The spermatozoa is also damaged by the constant changes of temperature in which the pre-freezing process was done for $5-9$ minutes at $-140^{\circ} \mathrm{C}$, freezing was done for 7 days of storage at $-196^{\circ} \mathrm{C}$ until the post-thawing process which took 15 seconds at a $37^{\circ} \mathrm{C}$.

Percentage of Viability of Frozen Semen of Aceh Cattle in the Skim Milk-Egg Yolk Extender with the Addition of Jamblang Leaves Extract during Pre-freezing and Post-thawing Process

Living spermatozoa test (viability) was employed as an indicator of the integrity of membrane structure. Data on the percentage of living spermatozoa (viability) on pre-freezing and post-thawing examinations after provided by treatments in various concentrations of jamblang leaves extract in diluent of skim milk-egg yolk are presented in Table 2.

Table 2. Percentage of Spermatozoa Viability of Aceh Cattle due to the Addition of Jamblang Leaves Extract in the Skim Milk-Egg Yolk Extender during Pre-freezing and Post-thawing

\begin{tabular}{|c|c|c|}
\hline \multirow[t]{2}{*}{ Treatments } & \multicolumn{2}{|c|}{ Observation Period } \\
\hline & Pre-freezing & Post-thawing \\
\hline $\mathrm{J} 0(0 \%)$ & $49.50^{\text {cd }} \pm 12.52$ & $33.12^{\mathrm{cd}} \pm 22.64$ \\
\hline $\mathrm{J} 1(0.2 \%)$ & $43.85^{\mathrm{bc}} \pm 5.04$ & $33.04^{b c} \pm 14.63$ \\
\hline $\mathrm{J} 2(0.4 \%)$ & $41.25^{\mathrm{a}} \pm 2.05$ & $28.41^{\mathrm{d}} \pm 3.95$ \\
\hline $\mathrm{J} 3(0.6 \%)$ & $56.59^{\mathrm{d}} \pm 1.21$ & $53.94^{\mathrm{d}} \pm 3.94$ \\
\hline $\mathrm{J} 4(0.8 \%)$ & $42.99^{\mathrm{ab}} \pm 4.76$ & $32.43^{\mathrm{ab}} \pm 5.77$ \\
\hline
\end{tabular}

The results of variance discovered that the addition of jamblang leaves extract in the skim milk-egg yolk extender significantly affected $(\mathrm{P}<0.01)$ the percentage of spermatozoa viability of Aceh cattle during the pre-freezing process. The results showed that the highest percentage of spermatozoa motility after pre-freezing was obtained from J3 treatment (skim milk-egg yolk + jamblang leaves extract $0.6 \%$ ) which was $56.59 \%$, while the lowest percentage of spermatozoa motility obtained from $\mathrm{J} 2$ treatment (skim milk-egg yolk + jamblang leaves extract $0.4 \%$ which was $41.25 \%$. The decrease in the percentage of living spermatozoa after pre-freezing process was caused by cold shock and damage to the spermatozoa membrane due to ice crystals which caused differences in osmotic pressure outside and inside the cell, thus it increases the death rate of spermatozoa. Khan and Ijaz (2008) stated that an increase in osmotic pressure in the semen plasma can reduce the permeability of spermatozoa membranes and increase damage to the membrane which leads to the death of spermatozoa. The results of previous research carried out by Pratiwi et al. (2014) obtained the percentage of viability of Simmental cattle spermatozoa using Andromed ${ }^{\circledR}$ in pre-freezing process for 9 minutes which was $58.17 \%$. The decrease in viability during prefreezing process was less than post-thawing process because the spermatozoa were adapting to cold temperatures during the pre-freezing process to prevent the death of more spermatozoa so that less damage can be obtained by the spermatozoa in the post-thawing process.

The average percentage of spermatozoa viability in the skim milk-egg yolk extender with additional of jamblang leaves extract during the post-thawing process is described in Table 2. The results of the variance stated that the addition of jamblang leaves extract in the skim milk-egg yolk extender significantly affected $(\mathrm{P}<0 \quad 0.05)$ the spermatozoa viability in Aceh cattle in the post-thawing process at $37^{\circ} \mathrm{C}$ for 15 seconds. Furthermore, $\mathrm{J} 3$ treatment 
(skim milk-egg yolk + jamblang leaves extract $0.6 \%$ ) showed the highest percentage $(53.94 \%)$ and were significantly different $(\mathrm{P}<0.05)$ with $\mathrm{J} 1, \mathrm{~J} 2$, and $\mathrm{J} 4$ treatments, but not different from $\mathrm{J} 0$ treatment (without the addition of jamblang leaves extract). The percentage of viability of Aceh cattle in this study was lower than the research results reported by Sukmawati et al. (2014) in Simmental cattle (61.72\%), limousine cattle (62.29\%), and FH cattle $(60.85 \%)$. The decrease in viability is still considered normal because according to Pesch and Bergmann (200), the decrease in the quality of spermatozoa after freezing is very high, which is around $50 \%$. Arifiantini et al (2006) claimed that artificial insemination needs $40-50 \%$ live and motile spermatozoa. Differences in decreased viability between individuals also possibly occur. According to Zahn et al. (2006), each individual has different protein composition of semen plasma and spermatozoa membranes and it is related to the resistance of spermatozoa to freezing. In addition, semen plasma proteins such as osteopoitin and lipocalin-clump prostaglandin D-synthase varied between males. Furthermore, Holden et al. (2017) stated that semen plasma composition is not homeostatic and varies not only between species but also between individuals and between ejaculations from the same animal.

The decrease in viability in the post-thawing process is due to the very low temperature during freezing. During semen processing, the environmental conditions of spermatozoa extremely change. Lemma (2011) stated that there are two temperature ranges that are susceptible to spermatozoa damage during freezing, those are the cooling period $\left(0^{\circ} \mathrm{C}\right.$ to $\left.-5^{\circ} \mathrm{C}\right)$ and ice crystal formation $\left(-6^{\circ} \mathrm{C}\right.$ to $\left.-15^{\circ} \mathrm{C}\right)$. The percentage of spermatozoa viability from prefreezing to post-thawing decreased. The decrease in the spermatozoa viability of Aceh cattle in the diluent of skim milk-egg yolk added with jamblang leaves extract with various concentrations is presented in the following Figure 2.

\section{Spermatozoa Viability Percentage during Pre-freezing and Post-thawing Process}

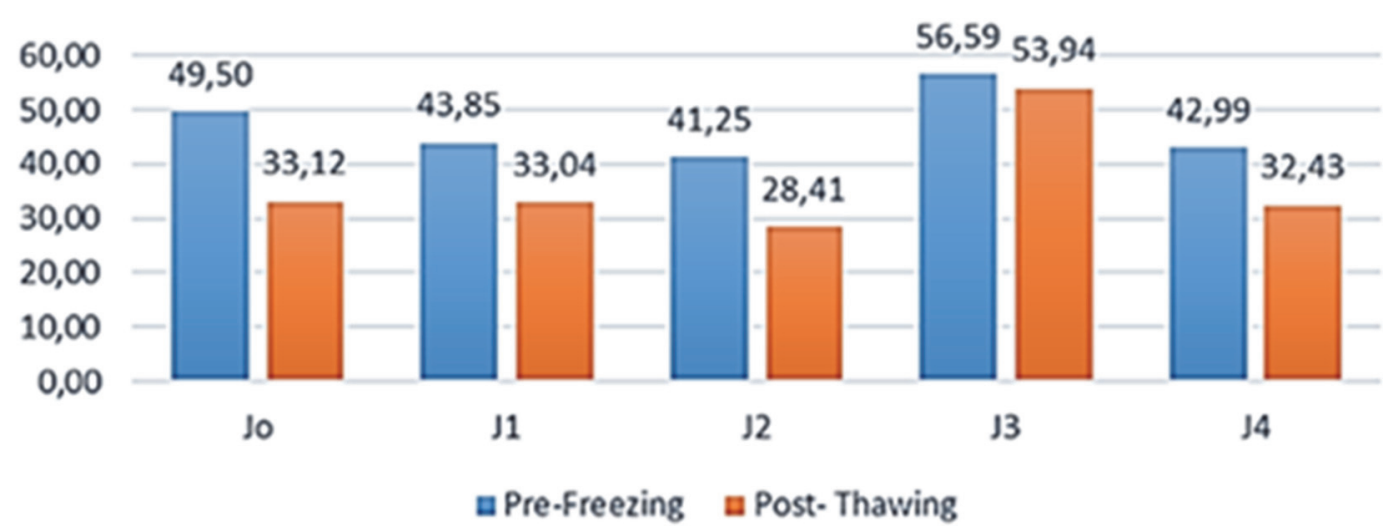

Figure 2. Comparison of Spermatozoa Viability Percentage during Pre-freezing and Post-thawing Process

Figure 2 shows that the decrease of viability percentage of in each treatment varies. J3 treatment (skim milk-egg yolk + addition of jamblang leaves extract of $0.6 \%$ ) provided the lowest percentage decrease of $4.68 \%$, while J0 treatment (without the addition of jamblang leaves extract) provided the highest percentage decrease of $33,09 \%$. This shows that the addition of jamblang leaves extract can reduce spermatozoa damage due to cold shock. Savitri et al. (2014) stated that the percentage of live spermatozoa in Bali cattle in the skim milk-egg yolk extender with additional vitamin $\mathrm{C}$ on post-thawing examination reached 54.33\%. Furthermore, Asadpour et al. (2012) claimed that the addition of superoxide dismutase (SOD) and butylated hydroxytoluene (BHT) in semen citrate egg-yolk (CEY) extender can increase the percentage of spermatozoa viability. Similar to vitamin C, SOD and BHT, jamblang leaves extract also contains antioxidants. According to Margaret et al. (2015) jamblang leaves extract contains alkaloids, flavonoids, terpenoids, steroids, phenolics, and saponins. In this case, Antioxidants play a role in binding oxygen radicals contained in cells to prevent the formation of lipid peroxidation which can inhibit glycolysis and motility.

\section{Conclusion}

Based on the results of this study, it was concluded that the addition of jamblang leaves extract in the skim milkegg yolk extender affected the percentage of spermatozoa motility and viability of Aceh cattle during pre-freezing 
and post-thawing. The best percentage of motility and viability was found in the concentration of jamblang leaves extract of $0.6 \%$ in $100 \mathrm{ml}$ of skim milk-egg yolk extender, both during pre-freezing and post-thawing.

\section{Suggestion}

It is expected that further research will be performed concerning the addition of jamblang leaves extract (Syzygium cumini) in other diluents in the frozen semen production process for Aceh cattle so that the best formulation of diluent media can be obtained in maintaining the quality of frozen semen of Aceh cattle.

\section{References}

Aboagla, E. M. E., \& Terada, T. (2004). Effects of egg yolk during the freezing step of cryopreservation on the $\begin{array}{lllll}\text { viability of goat } \quad \text { spermatozoa. } & \text { Theriogenology, } & \text { 62(6), }\end{array}$ https://doi.org/10.1016/j.theriogenology.2004.01.013

Affandhy, L., Adinata, Y., \& Aryogi. (2013). Evaluasi Kualitas Semen Pejantan Sapi PO Kebumen Di Kabupaten Kebumen Provinsi Jawa Tengah. Jurnal Sains Dasar, 2(2). https://doi.org/10.21831/jsd.v2i2.3299

Alcay, S. E., Gokce, M. B., Toker, N. T., Onder, B., Ustuner, E., Uzabaci, Z. Gul, \& Cavus, S. (2016). Freeze-dried egg yolk based extenders containing various antioxidants improve post-thawing quality and incubation resilience of goat spermatozoa. Cryobiology, 72(3), 269-273. https://doi.org/10.1016/j.cryobiol.2016.03.007

Amirat, L., D. Tainturier, L. Jeanneau, C. Thorin, O., Gerard, J. L., Courtens, M., \& Anton. (2004). Bull semen in vitro fertility after cryopreservation using egg yolk LDL: a comparison with optidyl, a commercial egg yolk extender. Theryogenology, 61, 895-907. https://doi.org/10.1016/S0093-691X(03)00259-0

Arifiantini, R. I., Yusuf, T. L., \& Yanti, D. (2005). Kaji Banding Kualitas semen beku sapi Friesian Holstein emnggunakan pengencer dari berbagai Balai Inseminasi Buatan di Indonesia. Animal Production, 7(3), 168176.

Asadpour, R., Jafari, R., \& Tayefi-Nasrabadi, H. (2012). The effect of antioxidant supplementation in semen extenders on semen quality and lipid peroxidation of chilled bull spermatozoa. Iranian Journal of Veterinary Research, Shiraz University, 13(3), Ser. No. 40, 246-249.

Basavaraja, N., \& Hedge, S. N. (2004). Cryopreservation of the endangered mahseer (Tor khudree) spermatozoa: I. Effect of extender composition, cryoprotectants, dilution ratio, and storage period on post-thaw viability. Cryobiology, 49(2), 149-156. https://doi.org/10.1016/j.cryobiol.2004.05.007

Baumber J., Ball, B. A., \& Linfor, J. (2005). Assesment of the cryopreservation of equine spermatozoa in the presence of enziyme scavengers and antioxidants. Am J Vet Red, 66, 772-779.

Baust, J. G., Gao, D., \& Baust, J. M. (2009). Cryopreservation: An emerging paradigm change. Review Series. Organogenesis, 5(3), 90-96. https://doi.org/10.4161/org.5.3.10021

Boujenane, I., \& Boussaq, K. (2013). Environmental effects and repeatability estimates for sperm production and semen quality of Holstein bulls. Arch. Anim. Breed., 56, 971-979. https://doi.org/10.7482/0003-9438-56-098

Brito, L. F. C., Silva, A. E. D. F., Rodrigues, L. H., Vieira, F. V., Deragon, L. A. G., \& Kastelic, J. P. (2002). Effects of environmental factors, age and genotype on sperm production and semen quality in Bos indicus and Bos taurus AI bulls in Brazil. Animal Reproduction Science, 70(3-4), 181-190. https://doi.org/10.1016/S03784320(02)00009-X

Bucak, M. N., Atessahin, A., \& Yuce, A. (2008). Effect of anti-oxidants and oxidative stress parameters on ram semen after the freeze-thawing process. Small Ruminant Research, 75(2-3), 128-134. https://doi.org/10.1016/j.smallrumres.2007.09.002

Buffone, M. G., Calamera, J. C., Brugo-Olmedo, S., De Vincentiis, S., Calamera, M. M., Storey, B. T., Doncel, G. F., \& Alvarez, J. G. (2012). Superoxide dismutase content in sperm correlates with motility recovery after thawing of cryopreserved human spermatozoa. Fertility and Sterility, 97(2), 293-298. https://doi.org/10.1016/j.fertnstert.2011.11.012

Chatterjee, S., \& Gagnon, C. (2001). Production of reactive oxygen species by spermatozoa undergoing cooling, freezing, and thawing. Moleculer Reproduction and Development, 59(4), 451-458. https://doi.org/10.1002/mrd.1052

Dewi, A. S., Ondho, Y. S., \& Kurnianto, E. (2012). Kualitas semen berdasarkaan umur pada sapi jantan jawa. Indian Vet J., 63, 909-912.

Ezzati, M., Shanehbandi, D., Hamdi, K., Rahbar, S., \& Pashaiasl, M. (2020). Influence of cryopreservation on 
structure and function of mammalian spermatozoa: an overview. Cell and Tissue Banking, 21, 1-15. https://doi.org/10.1007/s10561-019-09797-0

Feradis. (2009). Peranan antioksidan dalam pembekuan semen. Jurnal Peternakan, 6(2), 63-70. http://dx.doi.org/10.24014/jupet.v6i2.379

Ferramosca, A., \& V. Zara. (2014). Bioenergetics of mammalian sperm capacitation. Review Article. Biomed Research International, 2014, 1-8. https://doi.org/10.1155/2014/902953

Fraser, L., \& Strzezek, J. (2005). Effects of freezing-Thawing on DNA integrity of boar spermatozoa assessed by neutral comet assay. Reproduction in Domestic Animals, 40(6), 530-536. https://doi.org/10.1016/j.anireprosci.2006.06.003

Fuerst-Waltl, B., Schwarzenbacher, H., Perner, C., \& Solkner, J. (2006). Effects of age and environmental factors on semen production and semen quality of Austrian Simmental bulls. Animal Reproduction Science, 95(1-2), 27-37. https://doi.org/10.1016/j.anireprosci.2005.09.002

Garcia J. C., Dominguez, J. C., Pena, F. J., Alegre, B., Gonzalez, R., Castro, M. J., Habing, G. G., \& Kirkwood, R. N. (2010). Thawing boar semen in the presence of seminal plasma: Effects on Sperm quality and fertility. Animal Reproduction Science, 119, 160-165. https://doi.org/10.1016/j.anireprosci.2009.11.001

Gillan, L., Maxwell, W. M. C., \& Evans, G. (2004). Preservation and evaluation of semen for artificial insemination. Reproduction, Fertility and Development, 16(4), 447-454. https://doi.org/10.1071/RD04034

Gowri, S. S., \& Vasantha, K. (2010). Phytochemical screening and antibacterial activity of Syzygium cumini (L.) (Myrtaceae) Leaves Extracts. PhamTech Res., 2(2), 1569-1573.

Hafez, E. S. E. (2004). Reproduction in farm animals. $7^{\text {th }}$ edition. Lea and Febiger. Philadelphia.

Hanifi, H., Ihsan, M. N., \& Susilawati, T. (2016). Pengaruh Lama Ekuilibrasi pada Proses Pembekuan terhadap Kualitas Semen Sapi Wagyu menggunakan Pengencer Andromed ${ }^{\circledR}$. J. Ternak Tropika, 17(1), 31-41. https://doi.org/10.21776/ub.jtapro.2016.017.01.4

Holden, S. A., Fernandez-Fuertes, B., Murphy, C., Whelan, H., O’Gorman, A., Brennan, L., ... S. Fair. (2017). Relationship between in vitro sperm functional assessments, seminal plasma composition, and field fertility after AI with either non-sorted or sex-sorted bull semen. Theriogenology, 87, 221-228. https://doi.org/10.1016/j.theriogenology.2016.08.024

Januskauskas, A., Johannison, A., \& Rodriguez-Martinez. H. (2003). Subtle membrane changes in cryopreserved bull semen in relation with sperm viability, chromatin structure, and field fertility. Theriogenology, 60(4), 743-758. https://doi.org/10.1016/S0093-691X(03)00050-5

Khan, M. I. R., \& Ijaz, A. (2008). Effects of osmotic pressure on motility, plasma membrane integrity and viability in fresh and frozen-thawed buffalo spermatozoa. Animal, 2(4), 548-553. https://doi.org/10.1017/S1751731108001596

Komariah, I., Arifiantini, \& Nugraha, F. W. (2013). Kaji banding kualitas spermatozoa sapi simmental, limousine, dan Fresien holstein terhadap proses pembekuan. Buletin Peternakan, 37(3), 143-147.

Kostaman, T., \& Sutama, I. K. (2006). Studi motilitas dan daya hidup spermatozoa kambing boer pada pengencer tris-sitrat-fruktosa. J. Sain Vet., 24(1), 56-63.

Kumar, R., Mohanarao, G. J., Arvind \& Atreja, S. K. (2011). Freeze-thaw induced genotoxicity in buffalo (Bubalus bubalis) spermatozoa in relation to total antioxidant status. Molecular Biology Reports, 38, 1499-1506. https://doi.org/10.1007/s11033-010-0257-1

Kuswahyuni, I. S. (2009). Pengaruh lingkar skrotum dan volume testis terhadap volume semen dan konsentrasi sperma jantan simmental, limousin, dan brahman. Seminar Nasional Teknologi Peternakan dan Veteriner. Bandung.

Leao A. P. A., A. V. de Souza, N. F. Mesquita, L. J. Pereira, \& Zangeronimo, M. G. (2021). Antioxidant enrichment of roster semen extender - A systematic review. Research in Veterinary Science, 136, 111-118. https://doi.org/10.1016/j.rvsc.2021.02.005

Lemma, A. (2011). Effect of cryopreservation on sperm quality and fertility Artificial Insemination in Farm Animals. IntechOpen, 191-215.

Madyawati, S. P., Srianto, P., Dewi, C. P., Ismudiono, \& Sianita, N. (2011). Pengaruh penambahan tirosin kinase dalam bahan pengencer skim kuning telur dan Tris kuning telur terhadap persentase motilitas dan spermatozoa 
hidup sap Friesian Holstein post-thawing. J. Veterina Medika, 4(2), 87-90.

Mansour, N., Lahnsteiner, F., \& Patzner, R. A. (2010). Motility and cryopreservation of spermatozoa of European $\begin{array}{lllll}\text { common frog. } & \text { Rana temporaria. } & \text { Theriogenologi, } & 74,732 .\end{array}$ https://doi.org/10.1016/j.theriogenology.2010.03.025

Margaret, E., Shailaja, A. M., \& Rao, V. (2015). Evaluation of Antioxidant Activity in Different Parts of Syzygium cumini (Linn.). International Journal of Current Microbiology and Applied Sciences, 4(9), 372-379.

Mohamed, A. A., Ali, S. I., \& El-Baz. F. K. (2013). Antioxidant and antibacterial activities of crude extracts and essential oils of Syzygium cumini leaves. PLoS ONE, 8(4), e60269. https://doi.org/10.1371/journal.pone.0060269 10st August 2021

Nagy, S., Hallap, T., Johannisson, A., \& Rodriguez-Martinez, H. (2004). Changes in plasma membrane and acrosome integrity of frozen-thawed bovine spermatozoa during a $4 \mathrm{~h}$ incubation as measured by multicolor flow cytometry. Animal Reproduction $\quad$ Science, 80(3-4), https://doi.org/10.1016/j.anireprosci.2003.08.003

Nugraha, C. D., Herwijanti, E., Novianti, I., Furqon, A., Septian, W. A., Busono, W., \& Suyadi, S. (2019). Correlations between age of Bali bull and semen production at National Artificial Insemination Center, Singosari - Indonesia. J. Indonesian Trop. Anim. Agric., 44(3), 258-265.

Ozkavukcu, S., Erdemli, E., Isik, A., Oztuna, D., \& Karahuseyinoglu, S. (2008). Effects of cryopreservation on sperm parameters and ultrastructural morphology of human spermatozoa. Journal of Assisted Reproduction and Genetics, 25, 403-411. https://doi.org/10.1007/s10815-008-9232-3

Pagl, R., Aurich, J. E., Muller-Schlosser, F., Kankofer, M., \& Aurich, C. (2006). Comparison of an extender containing defined milk protein fractions with a skim milk-based extender for storage of equine semen at $5{ }^{\circ} \mathrm{C}$. Theriogenology, 66(50), 1115-1122. https://doi.org/10.1016/j.theriogenology.2006.03.006

Pesch, S., \& Bergmann, M. (2006). Structure of mammalian spermatozoa in respect to viability, fertility and cryopreservation. Micron, 37(7), 597-612. https://doi.org/10.1016/j.micron.2006.02.006

Petyim, S., Neungton, C., Thanaboonyawat, I., Laokirkkiat, P., \& Choavaratana, R. (2014). Sperm preparation before freezing improves sperm motility and reduces apoptosis in post-freezing-thawing sperm compared with post-thawing sperm preparation. Journal of Assisted Reproduction and Genetics, 31, 1673-1680. https://doi.org/10.1007/s10815-014-0332-y

Pratiwi, R. I., Suharyati, S., \& Hartono, M. (2014). Analisis kualitas semen beku sapi simmental menggunakan pengencer Andromed ${ }^{\circledR}$ dengan variasi waktu pre-freezing. Jurnal Ilmiah Peternakan Terpadu, 2(3), 8-15.

Pratiwi, W. C., Affandy, L., \& Ratnawati, D. (2006). Pengaruh Lama Thawing terhadap Kualitas Semen Beku Sapi Limousin dan Brahman. Animal Production, 11(1), 48-52.

Rasul, Z., Ahmad, N., \& Anzar, M. (2001). Changes in motion characteristic, plasma membrane integrity, and acrosome morphology during cryopreservation of buffalo spermatozoa. Journal of Andrology, 22(2), 278-283. https://doi.org/10.1002/j.1939-4640.2001.tb02181.x

Ratnawati, D., Affandhy, L., Pratiwi, W. C., \& Prihandini, P. W. (2008). Pengaruh pemberian suplemen tradisional terhadap kualitas semen pejantan sapi bali. Loka Penelitian Sapi Potong. Semarang.

Rodriguez-Martinez, H., Saravia, F., Wallgren, M., Roca, J., \& Pena, F. J. (2008). Influence of seminal plasma on the kinematics of boar spermatozoa during freezing. Theriogenology, 70(8), 1242-1250. https://doi.org/10.1016/j.theriogenology.2008.06.007

Ruan, Z. P., Zhang, L. L., \& Lin, Y. M. (2008). Evaluation of the antioxidant activity of Syzygium cumini leaves. Molecules, 13(10), 2545-2556.

Samsudewa, D., \& Suryawijaya, A. (2008). Pengaruh Berbagai Methode Thawing terhadap Kualitas Semen Beku Sapi. Seminar Nasional Tekhnologi Peternakan dan Veteriner. Fakultas Peternakan Universitas Dipenogoro. Semarang.

Santoso, H., Arifiantini, R. I., Gunawan, A., \& Sumantri, C. (2021). Characteristics and Potential Production of Frozen Semen of Pasundan Bull. Tropical Animal Science Journal, 44(1), $24-31$. https://doi.org/10.5398/tasj.2021.44.1.24

Sarma, N., Begum, T., Pandey, S. K., Gogoi, R., Munda, S., \& Lal., M. (2020). Chemical Composition of Syzygium cumini (L.) skeels leaf essential oil with respect to its uses from North East Region of India. Journal of 
Essential Oil Bearing Plants, 23(3). https://doi.org/10.1080/0972060X.2020.1796822

Savitri, F. K., Suharyati, S., \& Siswanto. (2014). Kualitas semen beku sapi bali dengan penambahan berbagai dosis vitamin C pada bahan pengencer skim kuming telur. Jurnal Ilmiah Peternakan Terpadu, 2(3), 30-36.

Schafer-Somi, S., Kluger, S., Knapp, E., Klein, D., \& Aurich, C. (2006). Effects of semen extender and semen processing on motility and viability of frozen-thawed dog spermatozoa. Theriogenologi, 66(2), 173-182. https://doi.org/10.1016/j.theriogenology.2005.10.022

Sholikah, N., Isnaini, N., Puspita Anugra Yekti, A., \& Susilawati, T. (2016). Pengaruh penggantian Bovine Serum Albumin (BSA) dengan putih telur pada pengencer CEP-2 terhadap kualitas semen sapi Peranakan Ongole pada suhu penyimpanan 3-5 ${ }^{\circ} \mathrm{C}$. Jurnal Ilmu-Ilmu Peternakan, 26(1), 7-15.

Sukmawati, E., Arifiantini, R. I., \& Purwantara, B. (2014). Daya tahan spermatozoa terhadap proses pembekuan pada berbagai jenis sapi pejantan unggul. Jurnal Ilmu Ternak dan Veteriner, 19(3), 168-175.

Sunami, S., Isnaini, N., \& Wahjuningsih, S. (2017). Kualitas semen segar dan recovery rate (RR) sapi limousine pada musim yang berbeda. J. Ternak Tropika, 18(1), 36-50.

Thuwanut, P., Chatdarong, K., Techakumphu, M., \& Axner, E. (2008). The effect of antioxidants on motility, viability, acrosome integrity and DNA integrity of frozen-thawed epididymal cat spermatozoa. Theriogenology, 70(2), 233-240. https://doi.org/10.1016/j.theriogenology.2008.04.005

Umar, S., \& Maharani, M. (2005). Pengaruh berbagai waktu ekuilibrasi terhadap daya tahan sperma Sapi Limousin dan uji kebuntingan. Jurnal Agribisnis Peternakan, 1(1), 17-21.

Zahn, F. S., Papa, F. O., \& Melo, C. M. (2006). Blood serum, seminal plasma and sperm membrane protein profiles in stallions; are they corelated to semen freezability? Anim. Reprod. Sci., 94, 64-66. http://dx.doi.org/10.1016/j.anireprosci.2006.03.088

Zulyazaini, Dasrul, S., Wahyuni, Akmal, M., \& Abdullah, M. A. N. (2016). Karakteristik semen dan komposisi kimia plasma seminalis sapi aceh yang dipelihara di BIBD Sare Aceh Besar. Jurnal Agripet, 16(2), 121130. https://doi.org/10.24815/jts.v\%25vi\%25i.5803

\section{Copyrights}

Copyright for this article is retained by the author(s), with first publication rights granted to the journal.

This is an open-access article distributed under the terms and conditions of the Creative Commons Attribution license (http://creativecommons.org/licenses/by/4.0/). 